\title{
USE OF BARN OWL (TYTO ALBA) PELLETS AS A POTENTIAL METHOD TO STUDY A RARE RODENT POPULATION IN NORTHEASTERN NEW MEXICO
}

\author{
Christopher B. Goguen ${ }^{1}$
}

\begin{abstract}
In June 2008, I discovered a single jumping mouse (Zapus) cranium in a Barn Owl (Tyto alba) pellet from below an active nest along Cerrososo Creek, Colfax County, northeastern New Mexico. Although the cranium could not be identified to species, this specimen could potentially represent a previously unknown population of the endangered New Mexico meadow jumping mouse (Z. hudsonius luteus). In 2009 and 2010, I collected pellets at 8 Barn Owl nesting or roosting sites along streams in my study area with the following objectives: (1) determine whether Barn Owl pellets could be used to gain information about the abundance and distribution of this Zapus population, (2) use pellets to acquire additional Zapus specimens to aid in positive identification of the jumping mouse species present, and (3) potentially document a previously unknown population of the endangered New Mexico meadow jumping mouse. Focusing only on pellets produced during the Zapus active (nonhibernation) summer period, I dissected 298 pellets containing 487 individual mammalian prey items from 12 genera but did not locate any additional Zapus remains. Examination of owl pellets appears to be a poor survey tool for Zapus, perhaps due to the jumping mouse's short summer active period, natural low population density, and preference for tall, dense riparian vegetation.
\end{abstract}

Resumen.-En junio del 2008, descubrí el cráneo de un ratón saltarín (Zapus) en la egagrópila (pellet) de una lechuza común (Tyto alba), debajo de un nido activo en Cerrososo Creek, Condado de Colfax, al noreste de Nuevo México. A pesar de que el cráneo no pudo ser identificado hasta especie, es posible que este espécimen pueda representar una población previa desconocida, de ratones saltarines de pradera en peligro de extinción (Z. hudsonius luteus) de Nuevo México. En los años de 2009 y 2010, colecté pellets de ocho nidos o refugios de lechuzas comunes a lo largo de arroyos de mi área de estudio, con los siguientes objetivos: (1) determinar si el pellet de una lechuza común puede ser utilizado para obtener información sobre la cantidad y la distribución de esta población de Zapus; (2) utilizar pellets para adquirir ejemplares adicionales de Zapus, y con ello, ayudar a la identificación positiva de la especie del ratón saltarín presente; y (3) documentar potencialmente una población desconocida de ratones saltarines de pradera en peligro de extinción en Nuevo México. Enfocándome únicamente en los pellets originados durante el período activo (de no hibernación) del Zapus, en verano, disequé 298 especímenes que contenían 487 partes individuales de presas de mamíferos de 12 géneros, pero no encontré restos adicionales de Zapus. Examinar los pellets de las lechuzas parece ser una herramienta pobre para obtener información sobre Zapus, quizás por el periodo activo en verano tan corto, a la densidad de la población naturalmente baja, y a sus preferencias por la vegetación alta, densa y ribereña.

Regurgitated pellets have long been used as a noninvasive method of studying the diet of raptorial bird species, particularly owls (Errington 1930). For generalist raptors, like the Barn Owl (Tyto alba), this technique has also been used to provide both quantitative and qualitative data on local populations of small mammals (Franzeb and Laudenslayer 1982, Marti 1988, Jorgensen et al. 1998), and to survey for rare or previously undocumented mammal species (Marti 1986, Velarde et al. 2007, Bonner and Geluso 2010).

On 19 June 2008, I discovered about one dozen fresh pellets below an active Barn Owl nesting burrow along Cerrososo Creek approximately $6 \mathrm{~km}$ east of the foothills of the
Sangre de Cristo Mountains in Colfax County, New Mexico (Fig. 1). Among the vertebrate remains within these pellets was a single jumping mouse (Zapus) cranium. Although the condition of the skull has thus far prevented positive identification to species, there are only 2 species of jumping mice present in Colfax County, New Mexico: the western jumping mouse (Z. princeps) and the meadow jumping mouse (Z. hudsonius), specifically the New Mexico meadow jumping mouse (Z. hudsonius luteus, hereafter NMMJM). Both species are strongly associated with riparian habitats, and both species are extremely similar in appearance, often requiring genetic or morphometric analyses for positive identification

${ }^{1}$ Science Program, Penn State University, 76 University Dr., Hazleton, PA 18202. E-mail: cbg10@psu.edu 


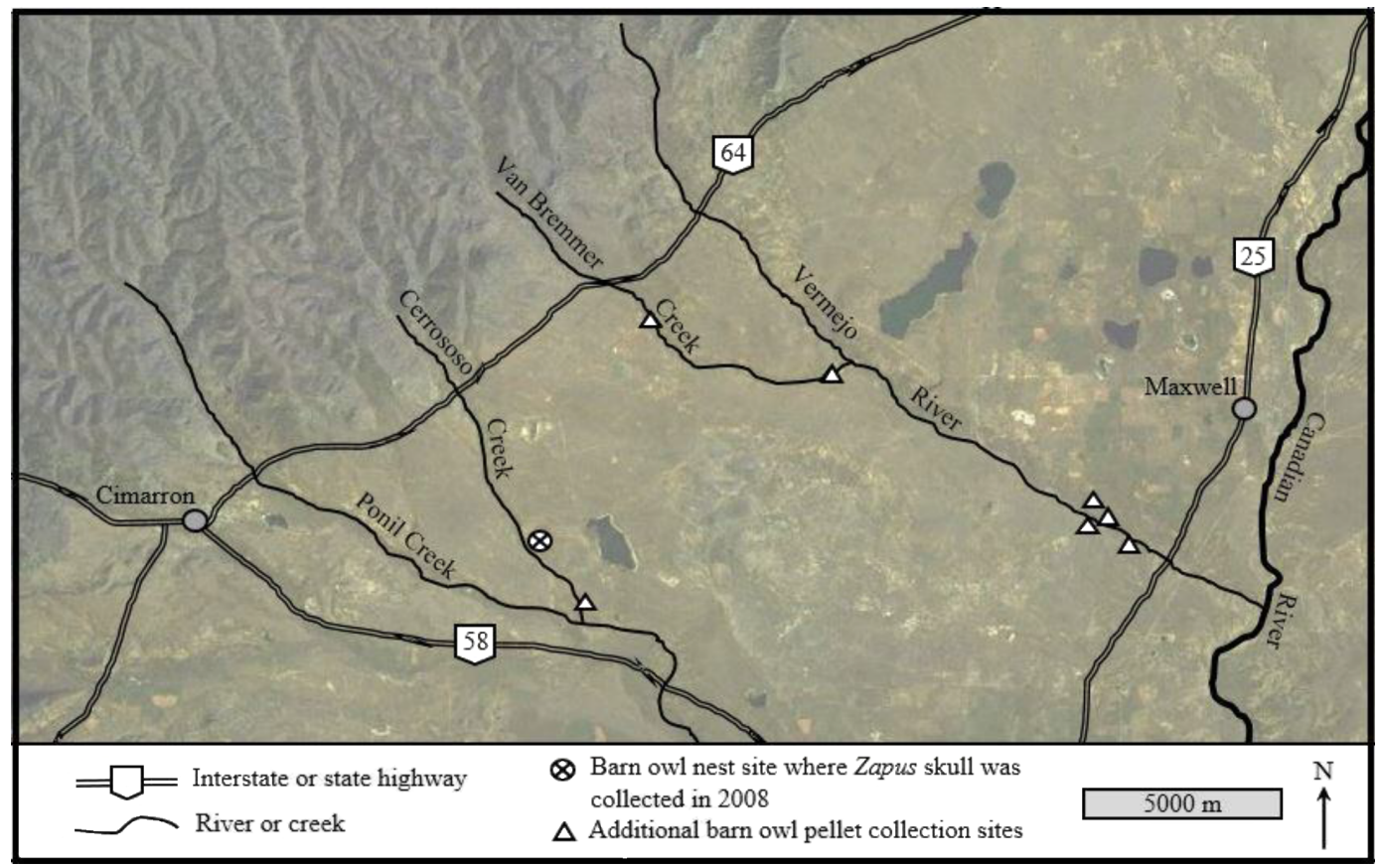

Fig. 1. Map of Barn Owl (Tyto alba) nesting or roosting sites on Vermejo Park Ranch, Colfax County, northeastern New Mexico at which pellets were collected during 2009 and 2010.

(Hafner et al. 1981). Both species also undergo a prolonged hibernation with an active period of only about 4-5 months each year (about mid-May to October) (Morrison 1990, Hart et al. 2004). The western jumping mouse is widely distributed in suitable habitats of the western United States, with the southern edge of its distribution reaching the Sangre de Cristo Mountains of northern New Mexico (Hart et al. 2004). Within New Mexico, this species typically inhabits areas of dense herbaceous vegetation under thickets of willow (Salix) and alder (Alnus) along cool montane streams (Findley 1987), but it can also occupy a wide range of scrub and coniferous forest habitats (Frey 2003). The NMMJM is extremely rare, currently surviving in $<30$ known small, isolated populations in New Mexico, southern Colorado, and eastern Arizona (U.S. Fish and Wildlife Service 2014). Two of these populations lie within $65 \mathrm{~km}$ of the collection site described in this paper: Sugarite Canyon, Colfax County, New Mexico/Las Animas County, Colorado (approximately $60 \mathrm{~km}$ northeast), and Coyote Creek, Colfax County, New Mexico (approximately $50 \mathrm{~km}$ southwest) (Frey 2012). The NMMJM is an extreme habitat specialist requiring riparian habitats with tall, dense herbaceous vegetation, particularly sedges (Cyperaceae), on saturated soils in proximity to flowing water (Frey and Malaney 2009, Wright and Frey 2015). It is also found primarily at lower elevations $(<2300 \mathrm{~m})$ in northern New Mexico than the western jumping mouse $(>2250 \mathrm{~m})$, although elevation alone cannot be used to identify the species (Frey and Malaney 2009, Frey 2012). Due to the small, isolated nature of this species' populations, the vulnerability of these remaining populations to habitat loss and degradation, and the species' low reproductive potential due to its brief active period, the NMMJM was federally listed as endangered in July 2014 (U.S. Fish and Wildlife Service 2014).

Given the possibility that my Zapus specimen could be from a previously unknown NMMJM population, I sought out additional Barn Owl nests in riparian habitats of my study site to attempt to learn more about this Zapus population. The objectives of my study were to (1) determine whether Barn Owl pellets could be used to gain information about the abundance and distribution of this Zapus population, (2) use pellets to acquire additional Zapus specimens 
to aid in positive identification of the jumping mouse species present, and (3) potentially document the presence of a previously unknown population of the endangered NMMJM.

My study was conducted within a 16,190-ha shortgrass prairie study area on the 233,603-ha Vermejo Park Ranch in Colfax County, northeastern New Mexico. The study area was located on the southeastern edge of the ranch approximately $5 \mathrm{~km}$ northeast of the town of Cimarron, and lay immediately east of the foothills of the Sangre de Cristo Mountains at an elevation of 1800-2000 m. Most of the study area consisted of shortgrass prairie dominated by perennial grasses, particularly blue grama (Bouteloua gracilis), interspersed with other grasses, forbs, shrubs, and cacti. This prairie habitat was transected by 4 streams supporting narrow strips of woody and herbaceous riparian habitat. The woody component of this habitat consisted of scattered Rio Grande cottonwood (Populus deltoides var. wislizenii) trees with occasional dense patches of willow and salt cedar (Tamarix chinensis). The herbaceous component consisted of a variety of forbs and graminoids, including large patches of grasses and sedges, particularly common three-square (Schoenoplectus pungens) and great bulrush (S. tabernaemontani). The dominant large herbivore within the study area was the American bison (Bison bison) in a managed herd. The study area was also the site of an active black-tailed prairie dog (Cynomys ludovicianus) restoration effort, with colonies covering about 3000 ha of grasslands (see Goguen 2012 for additional information).

Starting in mid-May 2009, I revisited the original Barn Owl nest on Cerrososo Creek and searched for additional nesting or roosting sites in stream banks and at potential humanmade sites along 3 of the streams in the pasture: Cerrososo Creek, Van Bremmer Creek, and the Vermejo River. Upon locating a potential owl site, I recorded evidence of use (e.g., flushing of an adult, activity or noise of young) and collected all fresh pellets beneath. During the remainder of the field season (through early July) I revisited each site every $2-4$ weeks to collect additional new pellets. During 2010, I revisited each owl site and collected pellets in a similar manner and during a similar time period as in 2009.

Collected pellets were either dissected immediately or were individually wrapped with foil and dried for approximately $1 \mathrm{~h}$ at $150{ }^{\circ} \mathrm{C}$ to kill potential pathogens until dissection could be completed. I dissected pellets using standard methods, identifying mammalian skull remains to the level of the genus using skull guides or keys (Jones and Manning 1992, Elbroch 2006). In some cases, I inferred identification to species when only one species of an identified genus was likely to be distributed in my study region. I did not attempt to further identify bird remains. To avoid double-counting of prey, only the total number of crania for each species was quantified in each pellet, although mandibles were often used to aid in identification.

In 2009, I collected pellets at 8 Barn Owl sites $(7$ nests and 1 roost; Fig. 1). Five of these sites were in burrows in vertical stream banks: 2 along Cerrososo Creek, 1 along Van Bremmer Creek, and 2 along the Vermejo River. The remaining 3 sites were all associated with human-made structures: 1 under a railroad bridge over Van Bremmer Creek, 1 in a deserted railroad boxcar approximately $170 \mathrm{~m}$ from the Vermejo River, and 1 in the attic of a deserted farmhouse approximately $240 \mathrm{~m}$ from the Vermejo River. In 2010, I revisited all of the owl sites but was only able to collect pellets at 5 sites as 3 of the burrows in stream banks had collapsed and were unoccupied (see Goguen and Klomps [in press] for a more detailed description of nest sites).

Because of their prolonged hibernation period, jumping mice were unlikely to be active before my first collection period in mid-May. Thus, I classified pellets from my initial visit to a nest site as "winter" pellets and assumed that most of these pellets would have been produced during the early spring or previous winter when jumping mice were unavailable as prey. Pellets collected at all later visits to the nests were classified as "summer" pellets. I focused my main analyses on summer pellets, as these pellets would likely have been produced after jumping mice emerged from hibernation.

In 2009, I collected 466 pellets from 8 owl sites $(\bar{x}=58.3$ pellets per site, range $26-114)$, consisting of 311 winter pellets and 155 summer pellets. In 2010, I collected 357 pellets from 5 owl sites $(\bar{x}=71.4$ pellets per site, range $21-$ 111 ), consisting of 214 winter pellets and 143 summer pellets. Seventy-seven of the summer pellets were collected from the Cerrososo Creek 
nest site at which the original Zapus had been detected (40 in 2009, 37 in 2010). Overall, I identified 1344 individual mammalian prey items (857 in winter pellets and 487 in summer pellets) from 12 genera, but did not locate any new Zapus remains. All 12 mammalian genera were present in the summer pellet sample (Table 1). Eleven of the 12 genera were present in the winter pellet sample, with only Eptesicus absent.

Although the incidental collection of a small number of Barn Owl pellets from a single nest site led to the discovery of a Zapus specimen in 2008, systematic collection of a large number of pellets at multiple riparian nest sites over the next 2 years failed to provide additional information about the abundance, distribution, or identity of the Zapus population on the study area. Based on habitat preferences of prey captured during the summer months (Table 1), Barn Owls foraged extensively in the upland arid grassland habitats that dominated the study area; more than half of the summer prey items consisted of uplanddwelling species (pocket gophers [Thomomys], kangaroo rats [Dipodomys], pocket mice [Perognathus and Chaetodipus], and grasshopper mice [Onychomys]). Species typically associated with moist habitats (voles [Microtus] and shrews [Sorex]) represented only $11.5 \%$ of the summer prey items but were found in pellets from all nest sites, suggesting that the owls spent at least some time foraging in riparian habitats. Generalist species (harvest mice [Reithrodontomys] and deer mice [Peromyscus]) represented about $30 \%$ of the summer prey items captured. Although these generalists could have been captured in a variety of microhabitats within the study area, Peromyscus and Reithrodontomys, along with Microtus, are typically among the most commonly captured genera at riparian sites where NMMJM are trapped (Frey 2006, 2012, Frey and Schwenke 2012, Frey and Wright 2012).

Several characteristics of Zapus behavior and ecology may contribute to the apparent low capture rate by Barn Owls. First, the short active period of Zapus greatly limits the time period during which jumping mice are exposed to Barn Owl predation. This short active period substantially reduced the number of pellets that I could acquire to potentially detect Zapus remains, especially relative to other prey species that were active year-round.
With the exception of Eptesicus, another hibernator which was detected just once in a summer pellet, all other prey taxa detected in my study are active year-round and were detected in both summer and winter pellets. Second, due to specialization on riparian habitats that are typically small and isolated, Zapus tend to be locally rare, making up only a minor proportion of the small mammal communities in which they live (Frey 2012). All 3 streams sampled in this study contained stretches of riparian habitat supporting tall, dense herbaceous vegetation appropriate for Zapus. American beaver (Castor canadensis) activity was also observed on all 3 streams; beaver can create high-quality riparian habitats on small streams, especially for the NMMJM (Frey and Wright 2012). However, these riparian habitats tended to be linear and narrow, and occupied far less area than the vast expanse of dry grassland that made up most of the area around Barn Owl nests. As a result, it is likely that a Zapus population would be quite small relative to populations of most other grassland and generalist prey species encountered, and thus would be expected to be a much rarer component of the Barn Owl's diet. Finally, the tendency of Zapus to live in tall, dense herbaceous vegetation may also protect them from aerial predators. Barn Owls are opportunistic predators but do favor some prey species over others (e.g., Gubanyi et al. 1992, Jorgensen et al. 1998, Stangl et al. 2005). This is perhaps due to differences in abundance or ease of capture among potential prey species. Perhaps the microhabitat preferences of Zapus make them difficult for Barn Owls to access. I could locate only one Barn Owl diet study in the Intermountain West that identified Zapus as prey; Marti (1969) found one Z. princeps out of 798 individual prey items identified in central Colorado. Of interest, Wright and Frey (2015) have recently documented a depredation of a radio-tagged NMMJM by a Great Horned Owl (Bubo virginianus) in south central New Mexico. It is likely that a short active period, rarity or natural low density, and preference for tall, dense vegetation all contribute to the low incidence of Zapus in Barn Owl diet.

Examination of Barn Owl pellets did not prove to be an effective survey technique; pellet examination over 2 years revealed no new information about this Zapus population. 


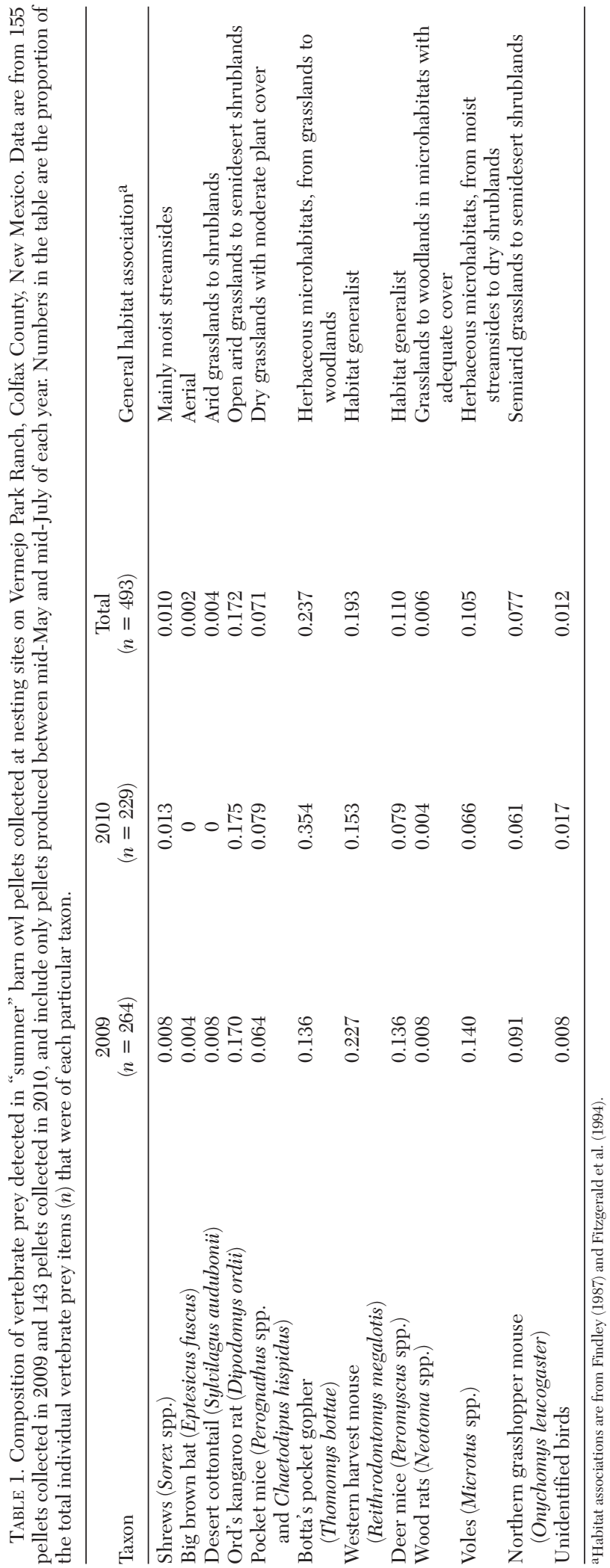


Further, in areas of potential sympatry of $Z$. princeps and Z. hudsonius, such as the Sangre de Cristo Mountains of northern New Mexico, it may be difficult to identify Zapus remains from pellets to species due to skull damage. With intact skulls, these 2 jumping mouse species can be reliably identified using a series of careful measurements (Frey 2007). Barn Owl digestion and pellet formation, however, typically damage fragile skeletal remains by breaking bones and by loosening sutures between bones, affecting the types of measurements possible and their accuracy. Both of these problems occurred with the single Zapus cranium I acquired in 2008. Given the small area and natural patchiness of many western riparian habitats, live-trapping is likely a much more efficient and effective survey technique for detecting and studying new populations of NMMJM (Morrison 1990, Frey and Schwenke 2012).

I thank the management of Vermejo Park Ranch for allowing me access to the property, and thank Larry Klomps, Louis Albanese, Bob Ward, and Lisa Goguen for their assistance with pellet collection and/or dissection. I also thank Jennifer Frey, New Mexico State University (NMSU) for examining and attempting to identify the Zapus skull I collected, and for providing comments on an early draft of this paper. The Zapus skull discussed in this paper is currently housed in the NMSU Vertebrate Wildlife Museum, catalog number NMSUVWM 2997. Funding and support for this research was provided by Faculty Research Development Grants from the Pennsylvania State University, Hazleton.

\section{Literature Cited}

Bonner, S.L., AND K. Geluso. 2010. Examination of owl pellets for northern pocket gophers at Crescent Lake National Wildlife Refuge, Nebraska. Prairie Naturalist 42:138-142.

Elbroch, M. 2006. Animal skulls: a guide to North American species. Stackpole Books, Mechanicsburg, PA.

ERRINGTON, P.L. 1930. The pellet analysis method of raptor food study. Condor 32:292-296.

FindLEY, J.S. 1987. The natural history of New Mexican mammals. University of New Mexico Press, Albuquerque, NM.

Fitzgerald, J.P., C.A. Meaney, and D.M. Armstrong. 1994. Mammals of Colorado. Denver Museum of Natural History and University Press of Colorado, Niwot, CO.

Franzeb, K.E., AND W.F. LaudensLAYER. 1982. Composition and seasonal variation of the Barn Owl (Tyto alba) diet in Arizona. Raptor Research 16:36-39.
FreY, J.K. 2003. Baseline inventory of small mammal prey-base communities on Carson National Forest, New Mexico. Final report submitted to Carson National Forest, Taos, New Mexico, 31 December 2003. $48 \mathrm{pp}$

Frey, J.K. 2006. Status of the New Mexico meadow jumping mouse (Zapus hudsonius luteus) in the Sangre de Cristo Mountains, New Mexico. Final report submitted to New Mexico Department of Game and Fish, Santa Fe, New Mexico, 14 December 2006. 78 pp.

FreY, J.K. 2007. Key to the rodents of New Mexico. Final report submitted to New Mexico Department of Game and Fish, Santa Fe, New Mexico, 4 June 2007. 120 pp.

FreY, J.K. 2012. Survey for the New Mexico meadow jumping mouse (Zapus hudsonius luteus) on Carson National Forest, New Mexico. Final report submitted to Carson National Forest, Taos, New Mexico, 5 December 2012. $71 \mathrm{pp}$.

Frey, J.K., and J.L. Malaney. 2009. Decline of the meadow jumping mouse (Zapus hudsonius luteus) in two mountain ranges in New Mexico. Southwestern Naturalist 54:31-44.

Frey, J.K., AND Z.J. SchwenKe. 2012. Mammals of Sugarite Canyon State Park, Colfax County, New Mexico. Occasional Papers, Museum of Texas Tech University 311:1-24.

Frey, J.K., AND G.D. Wright. 2012. Multiple scale habitat selection by a small mammal habitat specialist (Zapus hudsonius luteus) in a managed floodplain landscape. Final report submitted to U.S. Fish and Wildlife Service, Region 2, Albuquerque, New Mexico, 16 March 2012. 109 pp.

Goguen, C.B. 2012. Habitat use by Mountain Plovers in prairie dog colonies in northeastern New Mexico. Journal of Field Ornithology 83:154-165.

Goguen, C.B., AND L.V. Klomps. In press. Nest site use and diet of Barn Owls in northeastern New Mexico. New Mexico Ornithological Society Bulletin.

Gubanyi, J.A., R.M. Case, and G. Wingfield. 1992. Diet and nesting success of Barn Owls breeding in western Nebraska. American Midland Naturalist 127:224-232.

Hafner, D.J., K.E. Peterson, and T.L. Yates. 1981. Evolutionary relationships of jumping mice (genus Zapus) of the southwestern United States. Journal of Mammalogy 62:501-512.

Hart, E.B., M.C. Belk, E. Jordan, and M.W. Gonzalez. 2004. Zapus princeps. Mammalian Species 749:1-7.

Jones, J.K., AND R.W. Manning. 1992. Illustrated key to skulls of genera of North American land mammals. Texas Tech University Press, Lubbock, TX.

Jorgensen, E.E., S.M. SEll, and S. Desmarais. 1998. Barn Owl prey use in Chihuahuan Desert foothills. Southwestern Naturalist 43:53-56.

MARTI, C.D. 1969. Some comparisons of the feeding ecology of four owls in north-central Colorado. Southwestern Naturalist 14:163-170.

MarTI, C.D. 1986. Barn Owl diet includes mammal species new to the island fauna of the Great Salt Lake. Great Basin Naturalist 46:307-309.

Marti, C.D. 1988. A long-term study of the food-niche dynamics in the common barn-owl: comparisons within and between populations. Canadian Journal of Zoology 66:1803-1812.

Morrison, J.L. 1990. The meadow jumping mouse in New Mexico: habitat preferences and management recommendations. Pages 136-141 in P.R. Krausman 
and N.S. Smith, editors, Proceedings of the Symposium on Managing Wildlife in the Southwest. Arizona Chapter of the Wildlife Society, Phoenix, AZ.

Stangl, F.B., Jr., M.M. Shipley, J.R. Goetze, and C. Jones. 2005. Comments on the predator-prey relationship of the Texas kangaroo rat (Dipodomys elator) and Barn Owl (Tyto alba). American Midland Naturalist 153:135-141.

U.S. Fish AND WILDLIFE SERVICE. 2014. Endangered and threatened wildlife and plants: determination of endangered status for the New Mexico meadow jumping mouse throughout its range. Federal Register 79:33119-33137.
Velarde, E., R. Avila-Flores, and R.A. Medellin. 2007. Endemic and introduced vertebrates in the diet of the Barn Owl (Tyto alba) on two islands in the Gulf of California, Mexico. Southwestern Naturalist 52: 284-290.

Wright, G.D., AND J.K. Frey. 2015. Habitat selection by the endangered New Mexico meadow jumping mouse (Zapus hudsonius luteus) on an irrigated floodplain. Journal of Fish and Wildlife Management 6:112-129.

Received 5 March 2015 Accepted 4 November 2015 